\section{Cureus}

Received 06/19/2017

Review began 07/12/2017

Review ended 08/22/2017

Published 08/23/2017

\section{(c) Copyright 2017}

Tong et al. This is an open access article distributed under the terms of the Creative Commons Attribution License CC-BY 3.0., which permits unrestricted use, distribution, and reproduction in any medium, provided the original author and source are credited.

\title{
Familial Multiple Trichodiscomas: Case Report and Concise Review
}

\author{
Yun Tong ${ }^{1}$, Alvin B. Coda ${ }^{2}$, Jeremy A. Schneider ${ }^{1}$, Tissa R. Hata $^{1}$, Philip R. Cohen ${ }^{3}$ \\ 1. Department of Dermatology, University of California San Diego 2. Department of Dermatology, \\ Scripps Health 3. Department of Dermatology, University of California, San Diego
}

$\square$ Corresponding author: Yun Tong, larrytongmed@gmail.com

Disclosures can be found in Additional Information at the end of the article

\section{Abstract}

Familial multiple trichodiscomas is a condition characterized by multiple asymptomatic skin papules. The inheritance pattern has not been established. The skin lesions usually appear in childhood. The diagnosis of the cutaneous papules is established by pathologic evaluation. BirtHogg-Dubé syndrome is excluded by not detecting any aberration in the folliculin gene locus. Including our patient, 15 index individuals and their families are described. There is no systemic organ involvement or associated malignancies in individuals with this condition.

Categories: Dermatology

Keywords: irt-hogg-dubé, cancer, discoid, familial, fibromas, multiple, papules, trichodiscoma, folliculin

\section{Introduction}

Familial multiple trichodiscomas (Online Mendelian Inheritance in Man [OMIM] \# 190340), also known as familial multiple discoid fibromas, is a genodermatosis characterized by benign whitish-to-flesh-colored papules featured prominently on the face and ears. This condition shares morphological features with Birt-Hogg-Dubé syndrome (OMIM \# 135150); however, it is not linked to the folliculin (FLCN) gene locus and does not demonstrate pulmonary manifestations or associated visceral malignancy [1]. Familial multiple trichodiscomas has not been widely recognized as a separate condition from Birt-Hogg-Dubé syndrome [1]. Fourteen index individuals and their families have been previously reported. We describe a Chinese man with familial multiple trichodiscomas and review the characteristics of the previous patients with this condition.

\section{Case Presentation}

A 39-year-old man of Chinese descent without any significant past history presented for an evaluation of skin lesions on his head, neck and trunk. He commented that he had "always" had the papules. Yet, they had increased in size and number in recent years.

A detailed three-generation family history of 15 total members revealed no one with similar papules. However, the patient's mother was noted to have skin tags during pregnancy, which spontaneously resolved. Both of the patient's daughters, who are four years old and one year old, are currently asymptomatic.

The patient has no personal or family history of kidney cancers or pneumothoraces; however, a maternal aunt developed a gastrointestinal cancer and died in her 60s. 


\section{Cureus}

Cutaneous examination was remarkable for more than 50 pinpoint-to-two millimeter, firm, white-to-flesh-colored papules located on the face, ears, neck, and trunk (Figure 1). Two lesions located on his back were biopsied.

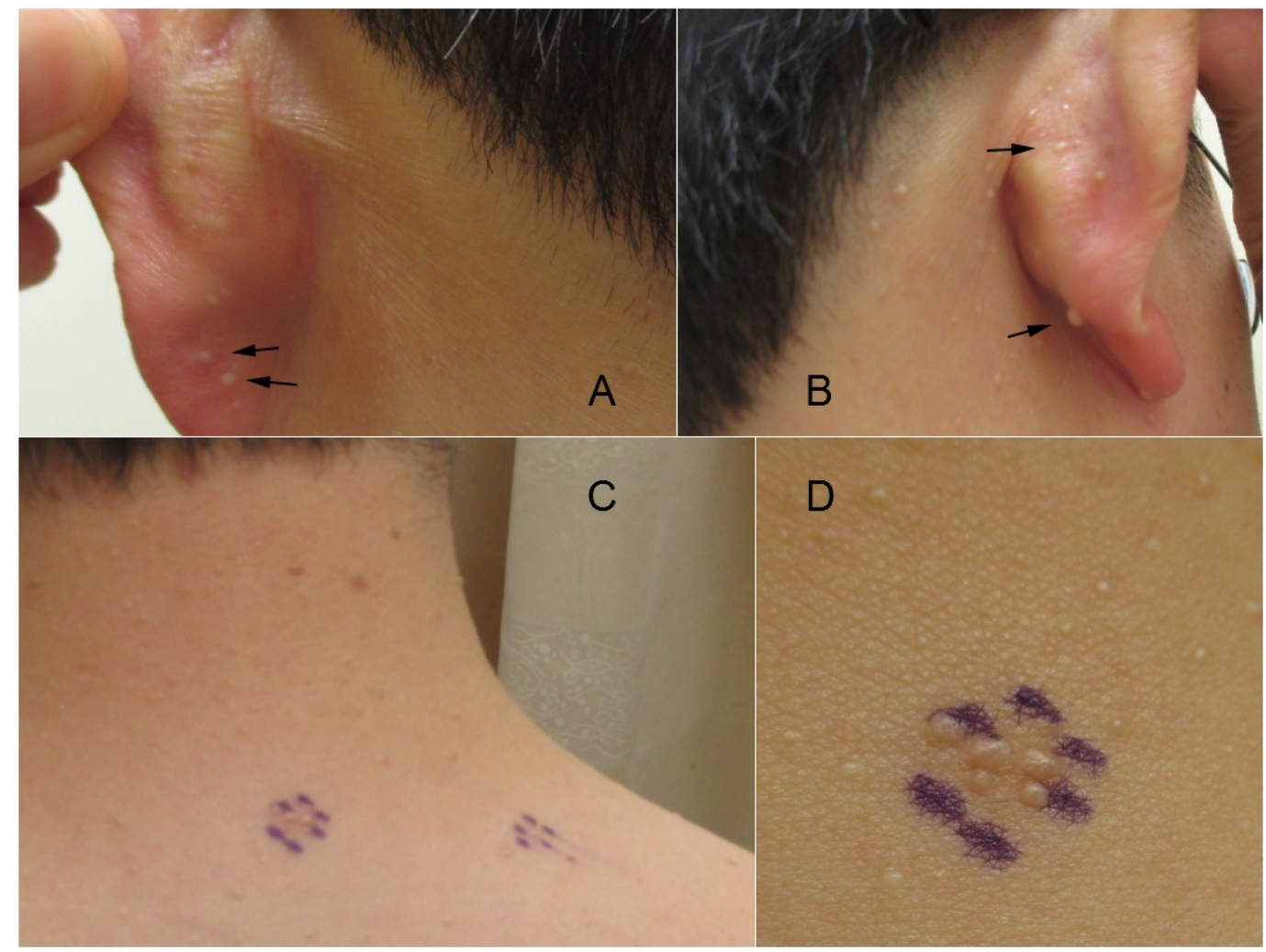

\section{FIGURE 1: Familial multiple trichodiscoma-associated} trichodiscomas.

Distant $(A, B, C)$ and closer $(D)$ views of trichodiscomas presenting as numerous 2-4 $\mathrm{mm}$ whitish papules on the left (A) and right (B) posterior aspect of the ears (arrows) and the right side of the upper back (lesions present within the areas circled in purple, C and D) of a 39-yearold man.

Microscopic evaluation of both lesions showed similar changes. There were an increased number of interstitial fibroblasts in the dermis. The mucin in the papillary dermis was also increased, which was confirmed by a colloidal iron stain (Figure 2). The pathology changes were consistent with the diagnosis of trichodiscoma. 


\section{Cureus}

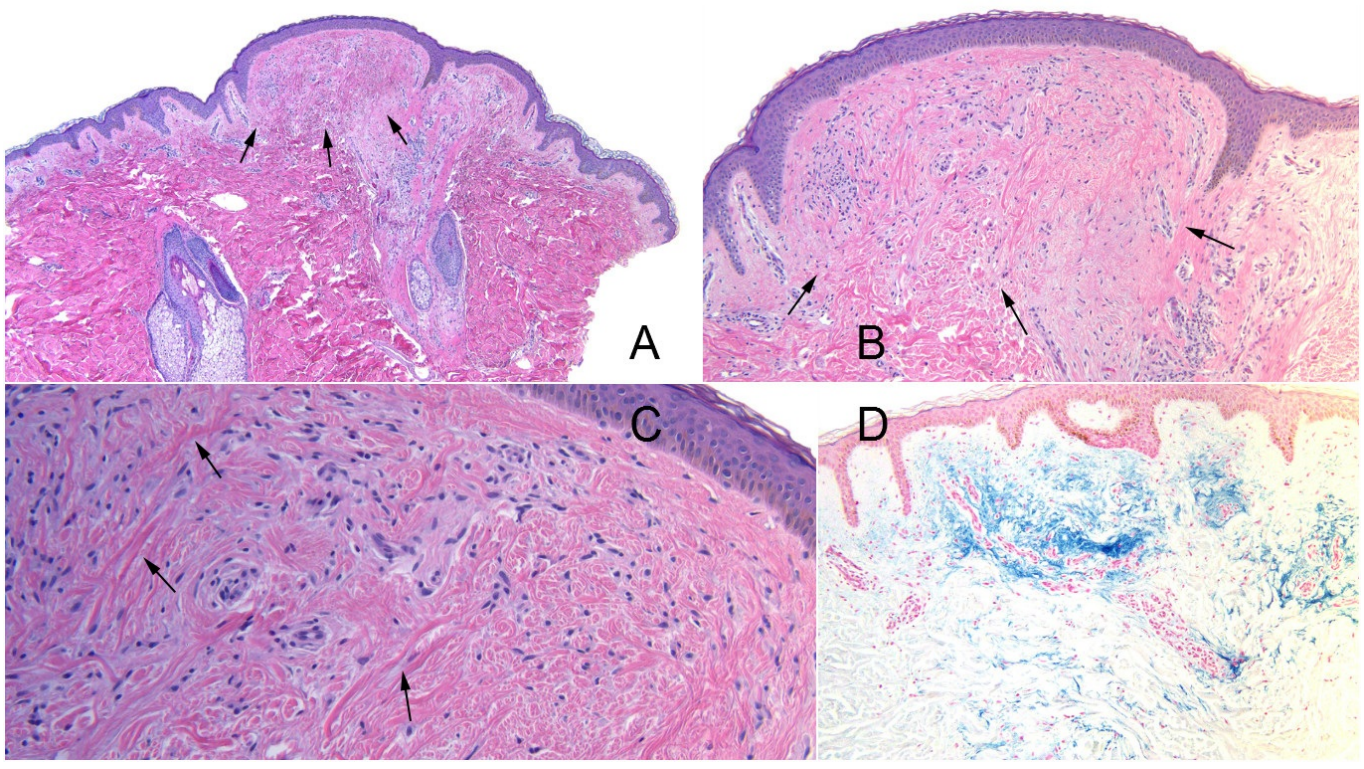

FIGURE 2: Histopathology of familial multiple trichodiscomaassociated trichodiscoma.

A punch biopsy of the trichodiscoma on the right side of the upper back of a 39-year-old man shows a dome-shaped papule in the center of the specimen which extends from an underlying hair follicle with an associated sebaceous gland; the three arrows demarcate the inferior border of the dermal papule (A and B). The overlying epidermis is flattened and the elongated epithelial rete ridges extend around the borders of the dermal tumor ( $A$ and $B$ ). Collagen deposition is increased around the blood vessels in the dermis (B and $C$ ); representative increased collagen fibers are demonstrated by arrows (C). The fibroblasts in the dermis are also increased (C). Mucin is increased in the dermal stroma ( $B$ and $D)$; the mucin appears blue after tissue sections are stained with colloidal iron (D) [hematoxylin and eosin: A, x4; B, x10; C, x20; colloidal iron: D, $\mathrm{x} 10]$.

The patient underwent genetic testing for the aberration of the folliculin gene locus. The results were negative for pathogenic mutations, variants of unknown significance, or gross deletions/duplications. Correlation of the clinical morphology and pathology of the skin lesions, the absence of associated systemic manifestations, and the lack of any aberration of the folliculin gene locus established the diagnosis of familial multiple trichodiscomas (Table 1) [1]. 


\section{Cureus}

\begin{tabular}{|c|c|c|}
\hline & Familial multiple trichodiscomas & Birt-Hogg-Dubé syndrome \\
\hline Lesion & Trichodiscoma & $\begin{array}{l}\text { Fibrofolliculoma, perifollicular fibroma, } \\
\text { and trichodiscoma }\end{array}$ \\
\hline $\begin{array}{l}\text { Morphological } \\
\text { feature }\end{array}$ & 1-4 mm papules & 1-4 mm papules \\
\hline $\begin{array}{l}\text { Location of } \\
\text { skin lesions }\end{array}$ & $\begin{array}{l}\text { Favors face, neck, and trunk; appearance on the ear's } \\
\text { pinna maybe pathognomonic }\end{array}$ & Favors face, neck, and trunk \\
\hline Age of onset & Early age, childhood & 30 s and older \\
\hline Inheritance & Likely autosomal dominant & Autosomal dominant \\
\hline $\begin{array}{l}\text { Systemic } \\
\text { associations }\end{array}$ & None & Lung cysts and pneumothoraces \\
\hline Malignancy & None & Yes (renal cancer) \\
\hline FLCNmutation & No & Yes \\
\hline
\end{tabular}

TABLE 1: Comparison of features in familial multiple trichodiscomas and Birt-HoggDubé syndrome.

\section{Discussion}

Trichodiscomas are benign fibrovascular hamartomas that present as small benign papules [2]. In 1977, Birt, Hogg, and Dubé noted trichodiscomas in a triad consisting with the simultaneous occurrence of fibrofolliculomas and acrochordons in a family, suggesting a genodermatosis now known as Birt-Hogg-Dubé syndrome [1]. Most reports of multiple trichodiscomas have been in patients diagnosed with Birt-Hogg-Dubé syndrome. However, a few reports have highlighted patients and family having multiple trichodiscomas without associated malignancies or systemic stigmata of Birt-Hogg-Dubé syndrome [1, 3-8]. These cases, without systemic manifestations or cancer, represent a distinct entity known as familial multiple trichodiscomas.

The incidence of familial multiple trichodiscomas is unknown [1, 6]. It is suspected that many cases prior to the availability of FLCN gene testing may have been misdiagnosed as Birt-HoggDubé syndrome. Although believed to be a genodermatosis separate from the FLCN gene, the familial multiple trichodiscomas gene has not been identified. While a negative FLCN makes Birt-Hogg-Dubé syndrome less likely, the possibility for an undiscovered mutation or variant continues to exist. Indeed, in Birt-Hogg-Dubé syndrome patients, only 91-93\% of germline pathogenic mutations can be detected [1-2].

The inheritance pattern of familial multiple trichodiscomas is unsettled. Autosomal-dominant inheritance has been described for a majority of the patients [1]. However, Wee, et al. also suggest an autosomal-recessive pattern of inheritance or germline mosaicism [6].

Familial multiple trichodiscomas have previously been described in 14 European individuals and their families (Table 2) [1, 3-8]. The largest case series come from the same authors who 


\section{Cureus}

initially suggested familial multiple trichodiscomas was a distinct entity from Birt-Hogg-Dubé syndrome [1]. In contrast to the previously reported individuals with familial multiple trichodiscomas, our patient is of non-European descent. Although none of our patient's relatives feature similar skin lesions, his high number of lesions and $F L C N$-negative result support our diagnosis of de novo familial multiple trichodiscomas in this individual.

\begin{tabular}{|c|c|c|c|c|c|c|c|c|c|c|c|}
\hline Ref. & Individual/family & Sex & Age at lesion onset & $\begin{array}{l}\text { Age at } \\
\text { presentation }\end{array}$ & $\begin{array}{l}\text { Location of } \\
\text { papules }\end{array}$ & Other lesions & FLCN & Malignancy & Systemic & $\begin{array}{l}\text { Nationality } \\
\text { of Pt }\end{array}$ & $\begin{array}{l}\text { Country of } \\
\text { report }\end{array}$ \\
\hline $\begin{array}{l}\text { Current } \\
\text { report }\end{array}$ & W-C & M & "Always had them" & 39 & Face, $\mathrm{P}, \mathrm{N}, \mathrm{T}$ & Acrochordons & Negative & Negative & None & Chinese & USA \\
\hline \multirow{3}{*}{ [7] } & Index Pt & M & 10 years prior & 29 & Face, P, L & Negative & Negative & Negative & None & Italian & Italy \\
\hline & Mother of index Pt & $\mathrm{M}$ & Not stated & Not stated & Face & Negative & $\begin{array}{l}\text { Not } \\
\text { done }\end{array}$ & Negative & None & Italian & Italy \\
\hline & $\begin{array}{l}\text { Maternal grandfather of } \\
\text { index Pt }\end{array}$ & $\mathrm{F}$ & 10 years prior & Not stated & Face & Negative & $\begin{array}{l}\text { Not } \\
\text { done }\end{array}$ & Negative & None & Italian & Italy \\
\hline \multirow{2}{*}{ [6] } & Index Pt & $M$ & 5 & 27 & Face, P, T, L & Negative & Negative & Negative & None & $\begin{array}{l}\text { Polish } \\
\text { origin }\end{array}$ & UK \\
\hline & Sister of index & $\mathrm{F}$ & Adolescence & 22 & Face, L & Negative & Negative & Negative & None & $\begin{array}{l}\text { Polish } \\
\text { origin }\end{array}$ & UK \\
\hline & Index Pt: 11 & $\mathrm{M}$ & 17 & 70 & Face, $P$ & legative & Positive & Negative & $\begin{array}{l}\text { Renal } \\
\text { cysts }\end{array}$ & Dutch & Netherlands \\
\hline & Family of 11 & $\mathrm{~F}$ & 22 & 42 & Face, $\mathrm{P}$ & legative & Positive* & Negative & None & Dutch & $\begin{array}{l}\text { The } \\
\text { Netherlands }\end{array}$ \\
\hline & Family of 11 & $\mathrm{~F}$ & 15 & 38 & Face, P, L & Negative & Positive $^{\star}$ & Negative & None & Dutch & Netherlands \\
\hline & Family of 11 & M & Not stated & Not stated & Not stated & lot stated & $\begin{array}{l}\text { Not } \\
\text { stated }\end{array}$ & Not stated & $\begin{array}{l}\text { Not } \\
\text { stated }\end{array}$ & Dutch & $\begin{array}{l}\text { The } \\
\text { Netherlands }\end{array}$ \\
\hline & Index Pt: 17 & M & 3 & 34 & Face, $\mathrm{P}$ & Negative & Negative & Negative & None & Dutch & Netherlands \\
\hline & Family of 17 & M & 1 & 6 & $P$ & Negative & Negative & Negative & None & Dutch & $\begin{array}{l}\text { The } \\
\text { Netherlands }\end{array}$ \\
\hline & Index Pt: 20 & $\mathrm{~F}$ & 18 & 44 & Face, $\mathrm{P}$ & Negative & Negative & Negative & None & Dutch & $\begin{array}{l}\text { The } \\
\text { Netherlands }\end{array}$ \\
\hline & Family of 20 & M & 5 & 14 & $\mathrm{P}$ & Negative & Negative & Negative & None & Dutch & $\begin{array}{l}\text { The } \\
\text { Netherlands }\end{array}$ \\
\hline & 24 - Index Pt & $\mathrm{F}$ & Early age & 59 & Face, $\mathrm{P}$ & Negative & Negative & Negative & None & Dutch & $\begin{array}{l}\text { The } \\
\text { Netherlands }\end{array}$ \\
\hline & Family of 24 & $\mathrm{~F}$ & Early age & 38 & Face, $\mathrm{P}, \mathrm{L}$ & Negative & Negative & Negative & None & Dutch & $\begin{array}{l}\text { The } \\
\text { Netherlands }\end{array}$ \\
\hline
\end{tabular}




\section{Cureus}

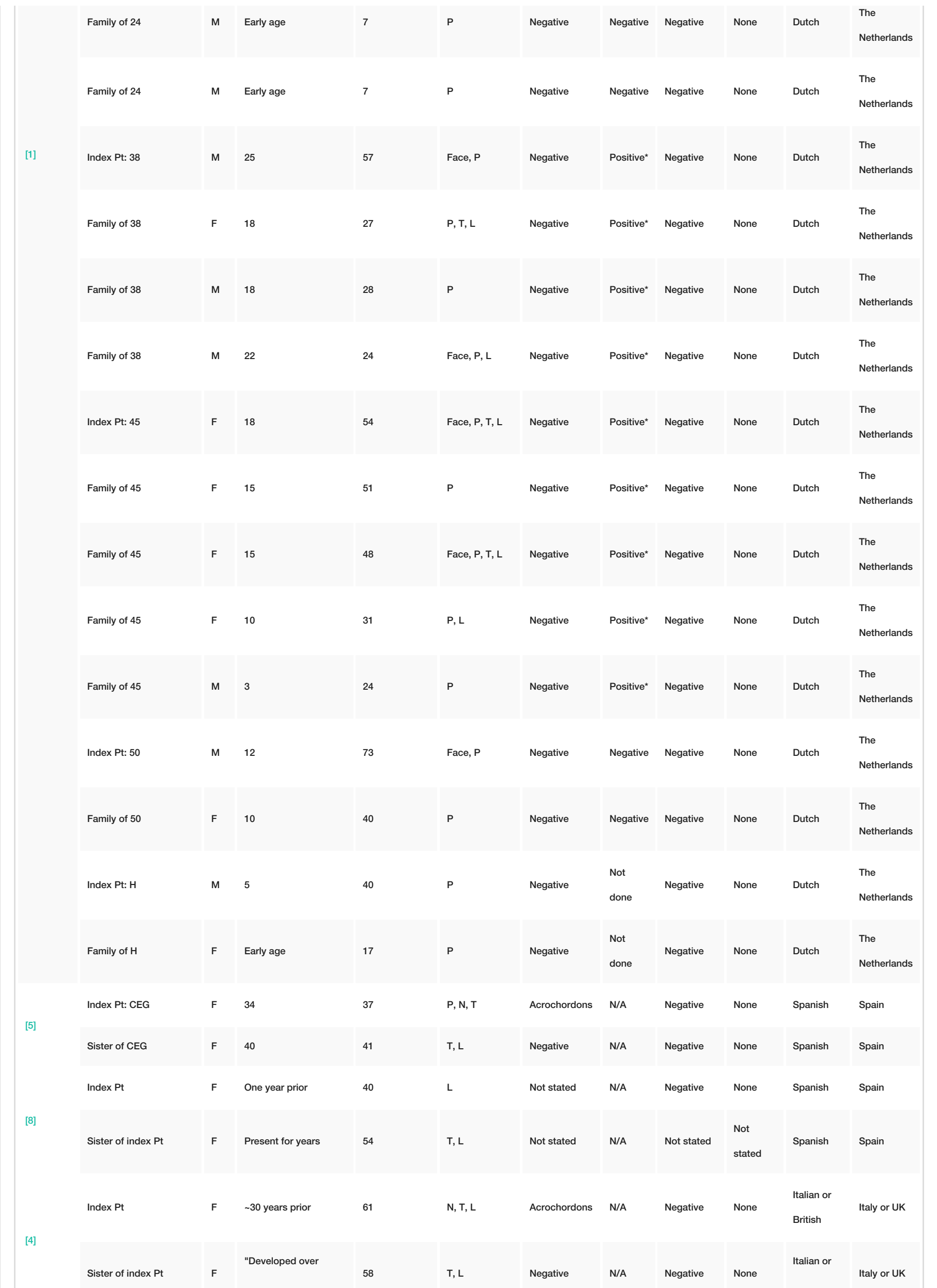




\section{Cureus}

\begin{tabular}{|c|c|c|c|c|c|c|c|c|c|c|c|}
\hline & & & several years" & & & & & & & British & \\
\hline \multirow{7}{*}[1,3]{} & Index Pt: T & $\mathrm{M}$ & 1 & 37 & Face, P, T, L & Acrochordons & N/A & Negative & None & Dutch & $\begin{array}{l}\text { The } \\
\text { Netherlands }\end{array}$ \\
\hline & Mother of $\mathrm{T}$ & $\mathrm{F}$ & At birth & 70 & Face, P, L & Negative & N/A & Negative & None & Dutch & $\begin{array}{l}\text { The } \\
\text { Netherlands }\end{array}$ \\
\hline & Maternal aunt of $\mathrm{T}$ & $\mathrm{F}$ & Early age & 73 & Face & Negative & N/A & Negative & None & Dutch & $\begin{array}{l}\text { The } \\
\text { Netherlands }\end{array}$ \\
\hline & Maternal uncle of $\mathrm{T}$ & M & Not stated & Deceased & Not stated & Not stated & N/A & Not stated & $\begin{array}{l}\text { Not } \\
\text { stated }\end{array}$ & Dutch & $\begin{array}{l}\text { The } \\
\text { Netherlands }\end{array}$ \\
\hline & Maternal uncle of $\mathrm{T}$ & $M$ & Not stated & Deceased & Not stated & Not stated & N/A & Not stated & $\begin{array}{l}\text { Not } \\
\text { stated }\end{array}$ & Dutch & $\begin{array}{l}\text { The } \\
\text { Netherlands }\end{array}$ \\
\hline & Maternal aunt of $\mathrm{T}$ & $\mathrm{F}$ & Not stated & Deceased & Not stated & Not stated & N/A & Not stated & $\begin{array}{l}\text { Not } \\
\text { stated }\end{array}$ & Dutch & $\begin{array}{l}\text { The } \\
\text { Netherlands }\end{array}$ \\
\hline & $\begin{array}{l}\text { Maternal grandmother } \\
\text { of } \mathrm{T}\end{array}$ & $\mathrm{F}$ & Not stated & Deceased & Not stated & Not stated & N/A & Not stated & $\begin{array}{l}\text { Not } \\
\text { stated }\end{array}$ & Dutch & $\begin{array}{l}\text { The } \\
\text { Netherlands }\end{array}$ \\
\hline
\end{tabular}

\section{TABLE 2: Characteristics of patients with familial multiple trichodiscomas.}

$\mathrm{F}$ = female; $\mathrm{L}$ = limbs; $\mathrm{M}$ = male; $\mathrm{N}$ = neck; N/A = not available; $\mathrm{P}=$ pinna; $\mathrm{Pt}$ = patient; Ref = Reference Article(s); $\mathrm{T}=$ trunk; UK = United Kingdom; USA = United States of America; ${ }^{*}=$ non-pathogenic FLCN variant; ${ }^{\wedge}=$ also negative for TSC1 (tuberous sclerosis 1) and TSC2 (tuberous sclerosis 2); ${ }^{\circ}=$ also negative for TSC1 (tuberous sclerosis 1), TSC2 (tuberous sclerosis 2), and PTEN (phosphatase and tensin homolog).

A subset of patients (Table 2: families 11, 38, and 45) tested positive for a non-pathogenic FLCN variant. It is unclear whether the non-pathogenic mutations are merely coincidental or a milder subtype of Birt-Hogg-Dubé syndrome. The investigators noted that the segregation analysis for two of the families (Table 2: families 11 and 45, which share a common ancestor) determined that involvement of the FLCN locus was excluded [1]. Family 38's mutation was a substitution of an evolutionarily nonconserved amino acid, which lead the researchers to conclude that the mutation was unlikely to have a pathogenic effect and did not cosegregate with the disease [1].

The morphologic features of familial multiple trichodiscomas-associated trichodiscomas are multiple 1-4 mm solid firm dome-shaped, flesh-colored papules. Typically there is a hair at or just outside the periphery of the lesion [3]. Many of the familial multiple trichodiscoma patients reported that their skin lesions appear in childhood; in contrast, the cutaneous lesions of BirtHogg-Dubé syndrome appear in middle age [1].

The preferential localization of trichodiscomas on the ear's pinnae, similar to our patient, may be a clinical feature that is characteristic for familial multiple trichodiscomas. In addition, the trichodiscomas of the ear in patients with familial multiple trichodiscomas may be larger with telangiectasias [1]. Similar to the trichodiscomas of familial multiple trichodiscomas, the fibrofolliculomas of Birt-Hogg-Dubé, usually have a central hair or follicular plug [1].

The pathological changes of a trichodiscoma classically present as a well-defined elliptical or discoid-shaped dermal tumor with flattened overlying epidermis [1]. At the periphery, there is elongated bend of the epidermis with converging rete ridges. The mantles have developed into 
sebaceous structures with ducts and mucin in trichodiscomas [9]. In contrast to the trichodiscoma of familial multiple trichodiscomas, the trichodiscomas of Birt-Hogg-Dubé syndrome have been shown to have identical anastomosing bands of fibrofolliculomas on deeper sectioning [2].

Fibrofolliculomas, the signature cutaneous feature of Birt-Hogg-Dubé syndrome, are characterized by epithelial strands of basaloid cells extending from the central and hyperplastic hair shaft infundibulum down into the dermis. Trichodiscomas of familial multiple trichodiscomas do not have any features of fibrofolliculomas on deeper sections. In contrast, the trichodiscomas of Birt-Hogg-Dubé syndrome have anastomosing bands, identical to those of fibrofolliculomas, on deeper sectioning. Hence, since the trichodiscomas of familial multiple trichodiscoma do not transition into fibrofolliculomas after deeper sectioning of the biopsy, they represent a distinct pathology separate from that observed in the trichodiscomas of BirtHogg-Dubé syndrome [1]. Therefore, in order to avoid further confusion with the trichodiscomas of Birt-Hogg-Dubé syndrome, the original coiners of familial multiple trichodiscomas have attempted to rename the familial multiple trichodiscoma-associated trichodiscomas as discoid fibromas and the disease entity as familial multiple discoid fibromas $[1,6]$.

Evaluation for an individual in whom the diagnosis of familial multiple trichodiscomas is being considered begins with a detailed history of the onset of their skin lesions, whether there is a family history of similar lesions, and a review of the personal and family history of potentially associated systemic findings such as pneumothoraces or visceral malignancy, such as renal cell carcinoma. Lesion biopsy should be performed; multiple step sections should be evaluated to rule out the trichodiscoma transition to fibrofolliculoma which is observed in Birt-Hogg-Dubé syndrome but is absent in familial multiple trichodiscomas. $F L C N$ gene locus testing should be performed; a negative result for a pathogenic gene aberration is consistent with familial multiple trichodiscomas.

As benign lesions, trichodiscomas do not require treatment. Trichodiscomas of familial multiple trichodiscomas are morphologically similar in appearance to the fibrofolliculomas of Birt-Hogg-Dubé syndrome; therefore, similar treatments with lasers or hyfrecation, with or without curettage, may be effective. However, Wee, et al. reported unsatisfactory results after hyfrecation with curettage or shave excision [6].

Topical rapamycin was effective for the treatment of trichodiscomas in a familial multiple trichodiscoma patient; yet, it was not successful for the fibrofolliculomas and trichodiscomas in patients with Birt-Hogg-Dubé syndrome [6, 10]. This observation may provide indirect evidence that the two entities are distinct [6]. However, the improvement with rapamycin also suggests the purported gene involved in familial multiple trichodiscomas may be localized to the mechanistic target of rapamycin (mTOR) pathway, for which Birt-Hogg-Dubé has also been shown to have an intimate relationship [2].

Our review of literature - including the currently described individual - shows 15 families (44 patients) who were diagnosed with familial multiple trichodiscomas (Table 2). Their age of onset is usually younger than that of Birt-Hogg-Dubé syndrome. The lesion location was described in 39 patients: 35 had papules on the head and neck (face, neck, ear's pinna). If lesions on the pinna are used as a specific finding of familial multiple trichodiscomas, 30 of the 35 patients with descriptions of their trichodiscoma locations were positive. A search for other types of skin lesions was described in 37 of the 44 patients; only four of these individuals also had concurrent acrochordons. Including our patient, evaluation for potentially associated systemic findings was described in 38 patients; only one individual had renal cysts. Likewise, the presence of visceral malignancy was evaluated in 38 patients; none of them had cancer. 


\section{Conclusions}

Familial multiple trichodiscomas is a benign condition associated with multiple skin lesions and no systemic manifestations or genomic aberrations. It is characterized by multiple small flesh-colored-to-whitish papules on the head, neck and upper trunk with prominent involvement of the ear's pinnae. The differential diagnosis of familial multiple trichodiscomas is Birt-Hogg-Dubé syndrome. Although both conditions have cutaneous trichodiscomas, familial multiple trichodiscoma patients do not have condition-associated pulmonary pneumothoraces, visceral cancer, or aberration of the FLCN gene locus.

\section{Additional Information}

\section{Disclosures}

Human subjects: Consent was obtained by all participants in this study. Informed consent obtained. Conflicts of interest: In compliance with the ICMJE uniform disclosure form, all authors declare the following: Payment/services info: All authors have declared that no financial support was received from any organization for the submitted work. Financial relationships: All authors have declared that they have no financial relationships at present or within the previous three years with any organizations that might have an interest in the submitted work. Other relationships: All authors have declared that there are no other relationships or activities that could appear to have influenced the submitted work.

\section{References}

1. Starink TM, Houweling AC, van Doorn MBA, et al.: Familial multiple discoid fibromas: a lookalike of Birt-Hogg-Dubé syndrome not linked to the FLCN locus. J Am Acad Dermatol. 2012, 66:259.e1-259.e9. 10.1016/j.jaad.2010.11.039

2. Tong Y, Schneider JA, Coda AB, et al.: Birt-Hogg-Dubé syndrome: a review of dermatological manifestations and other symptoms. Am J Clin Dermatol. 2017, 1-15. 10.1007/s40257-0170307-8

3. Starink TM, Kisch LS, Meijer CJ: Familial multiple trichodiscomas. A clinicopathologic study . Arch Dermatol. 1985, 121:888-891. 10.1001/archderm.1985.01660070078019

4. Balus L, Crovato F, Breathnach AS: Familial multiple trichodiscomas. J Am Acad Dermatol. 1986, 15:603-607. 10.1016/S0190-9622(86)70211-9

5. Alsina MM, Ferrando J, Bombi JA, et al.: [Multiple familial trichodiscoma] (article in Spanish) . Med Cutan Ibero Lat Am. 1990, 18:30-34.

6. Wee J, Chong H, Natkunarajah J, et al.: Familial multiple discoid fibromas: unique histological features and therapeutic response to topical rapamycin. Br J Dermatol. 2013, 169:177-180. 10.1111/bjd.12315

7. Neri I, D’Acunto C, Pileri A, et al.: Multiple familial trichodiscomas. Cutis. 2014, 93:E6-E7.

8. Camarasa JG, Calderon P, Moreno A: Familial multiple trichodiscomas. Acta Derm Venereol. 1988, 68:163-165.

9. Kacerovska D, Michal M, Kazakov DV: Trichodiscoma with lipomatous metaplasia and pleomorphic stromal cells. J Cutan Pathol. 2010, 37:1110-1111. 10.1111/j.16000560.2010.01572.x

10. Gijezen LMC, Vernooij M, Martens H, et al.: Topical rapamycin as a treatment for fibrofolliculomas in Birt-Hogg-Dubé syndrome: a double-blind placebo-controlled randomized split-face trial. PloS One. 2014, 9:e99071. 10.1371/journal.pone.0099071 